thrown back at them by the accused. The far-right media are awash in reports of "lesbo-fascists," "eco-fascists," "Islamo-fascists," "body fascists," "technofascists," "homo-fascists," and even "liberal fascists." In short, if there is indeed a fascist creep, as Ross supposes, one wonders where it is really coming from: the right or the left?

In 1944 George Orwell wrote that "the word 'fascism' ... is almost entirely meaningless, except in so far as it signifies 'something not desirable'." If nothing else, Against the Fascist Creep offers proof.

James Aho

Idaho State University

\title{
Anne James, Poets, Players, and Preachers: Remembering the Gunpowder Plot in Seventeenth-Century England (Toronto: University of Toronto Press, 2016). 412 pp. Hardback \$85.00.
}

In both the historical and popular imagination, the 1605 Gunpowder Plot is often treated as a singular event, a turning point that led to the Oath of Allegiance and the domestic and international conflicts that accompanied it. Anne James's Poets, Players, and Preachers: Remembering the Gunpowder Plot in Seventeenth-Century England, by contrast, takes the plot and situates it within a context of religious conflict and growing nationalism that began in the late sixteenth century and extended well into the seventeenth. To chart this longer history James focuses on how literary responses to the plot-occurring as they did in public ritual, stage plays, epic poetry, and occasional sermons_-developed and reformed with the passage of time. The result is a fine example of the iterative relationship between literary and historical inquiry, as well as a complex account of how the memory of a single (and ultimately failed) historical event can come to serve widely divergent ends.

Central to James's analysis is an interest in genre, in particular how successive textual renditions of the Gunpowder Plot not only evidence the motives of their authors but how the process of historical reinterpretation generates changes in literary form. As an analytical frame, genre has several benefits for James's study, perhaps the most important of which is that it attends both to the structure of an individual text and to the expectations and reception that text met in its audience. Genre also offers the opportunity to chart literary developments across a longer historical period, as each moment of interpretation thus simultaneously relies on events and texts that have already gone before it and provides the foundation for subsequent readings. Such processes, James details, could be exploited for particular political ends. Official liturgies and sermons produced in the immediate aftermath of the plot, for example, helped advance King James I's 1606-07 attempts for union between Scotland and England. They did so by comingling his deliverance in Scotland from the 1600 Gowrie Conspiracy with 
the longer history of English deliverances from Catholic conspiracy under Elizabeth, creating thereby one national tradition of salvation in which the Gunpowder Plot became the unified terminus of the two nations's independent histories. At the same time, however, the narrative of the plot was itself subject to revision, with later accounts variously accommodating themselves to more complex understandings of tragicomedy and, in the pens of Catholic respondents, with a tradition of martyrology that served to emphasize the unjust persecution of English Catholics (and their Jesuit priests) rather than their civil disloyalty.

As James explains, theatrical responses to the plot similarly varied their authors working not only within these competing narratives but also the evolving dramatic conversation that occurred as elements of the conspiracy were performed and reformed in the law courts and on the stage. To explore this dynamic, in what is the most strictly literary section of her book, James first sets a series of early plays-John Day's The Isle of Gulls, Ben Jonson's Volpone, and Thomas Dekker's The Whore of Babylon (all 1606-7) — in relation to each other before turning to what she reads as Jonson's subsequent reexamination of the plot in his later Cataline, his Conspiracy (1611). The three early plays helped establish the stage as a location where the official narrative of the plot could be variously deliberated, the role of Robert Cecil coming under particular if indirect scrutiny. Jonson's later Cataline, by contrast, demonstrates how a generic shift could serve more pointed political purposes. In particular, Jonson's move from the comedy of Volpone to the emphasis on personal ambition in tragedy would enable a broader assault on the ambition of not only Cecil but also the earls of Salisbury and Northumberland, all of whom-in James' reading - are figured in the opportunism and rhetoric of the character Cicero (106-108).

Attention to genre, of course, also demands attention to the capacity of an audience to understand and apply generic expectations to interpretative moments. Where the public theater by definition was open to a wide range of individuals, the Latin epic — a literary form that occupies the middle chapters of this book-presupposes a more select group of authors and their audiences. Here the broadly popular nature of the stage is replaced by a fragmented polity, as James charts how in successive epics early Stuart authors moved from attempts at courtly patronage to a more militant Protestantism characterized by an increasing disillusionment with the role of the monarch in promoting further religious reform. Her examples here are both familiar (John Milton's early Cambridge poem In Quintum Novembris) and lesser-known, the latter including poems by Francis Herring and his subsequent translator John Vicars. Vicars is a useful example of the changes James seeks to track, for in twice $(1617,1641)$ translating Herring's work Vicars shows a tendency not toward Vergilian epic but to the romance form. James attributes this shift in part to the growing sense among the godly that the Jacobean frustration of the Gunpowder Plot had done little to halt the pernicious progress of English Catholicism. James then returns to Milton, read- 
ing in Paradise Lost's depiction of the war in heaven-and in particular Satan's discovery and deployment of gunpowder against his angelic opponents-echoes not only of the Irish Rebellion (1641) but of the increasing disagreement among some Protestants over the role that any monarch might have in guiding the beliefs of England's truly faithful remnant (173-186).

The long-term contours of this shift from official narrative to popular fragmentation reappear in James' final substantive chapter, which examines four different political sermons by John Donne (1622), Henry Burton (1636), Matthew Newcomen (1642), and Seth Ward (1661). In many ways this chapter evidences the best elements of James's book, juxtaposing more immediately familiar texts and authors with works less familiar as a means to elucidate how the events of November 1605 echoed throughout the seventeenth-century, and how as late as 1688 this failed rebellion continued to provide the raw material necessary for authors of all sorts to explicate the longer national histories-political, religious, and literary - that informed their own individual compositions. Though the initial narrative of the thwarted plot was carefully structured to advance official state policy, as James's book carefully demonstrates the reception and reinterpretation of this account rapidly outpaced its origin, becoming instead a memory limned by the political and religious polarization of the years that followed.

Todd Butler

Washington State University

\section{Alix R. Green, History, Policy and Public Purpose: Historians and Histori- cal Thinking in Government (London: Palgrave Macmillan, 2016). 146 pp. Hardback \$67.00.}

Since the election of Donald Trump, academic historians in the United States have wrestled with how to respond to a political situation that many perceive as a crisis: Should they simply offer their insights and potential guidance to a diffuse coalition of resistance movements? Should they seek to influence public discourse and debate more generally? Or, over the long-term, should they seek a more direct role in government and policymaking? Although none of these are new questions, they suddenly became more pressing following the 2016 election.

Written just before Trump's victory, and from the perspective of the United Kingdom, Alix R. Green's History, Policy and Public Purpose: Historians and Historical Thinking in Government offers a timely and provocative, but ultimately incomplete, contribution to this discussion. Green's work offers keen insights into what historians might bring to the policy world, as well as sharp assessments of our current shortcomings. Yet the book loses focus on its core question of how historians might contribute to policymaking and too often turns inward towards 